\title{
Mycorrhizal Association in Wheat Genotypes Submitted to Variable Irrigation in the Brazilian Cerrado
}

\author{
Daniel Fernando Salas Méndez ${ }^{1}$, Alessandra Monteiro de Paula ${ }^{1}$, Maria Lucrécia Gerosa Ramos ${ }^{1}$, \\ Walter Quadros Ribeiro Junior ${ }^{2}$, Jader Galba Busato ${ }^{1}$, Guilherme Filgueira Soares ${ }^{1} \&$ Cristiane Andréa de Lima ${ }^{2}$ \\ ${ }^{1}$ Central Science Institute, Faculty of Agronomy and Veterinary Medicine, University of Brasília, Darcy Ribeiro \\ Campus, Brasília, DF, Brazil \\ ${ }^{2}$ Embrapa Cerrados, Planaltina, DF, Brazil \\ Correspondence: Alessandra Monteiro de Paula, Central Science Institute, Faculty of Agronomy and Veterinary \\ Medicine, University of Brasília, Darcy Ribeiro Campus, Brasília, DF, Brazil. Tel: 55-613-107-7163. E-mail: \\ alessandramp@unb.br
}

Received: August 23, 2021

Accepted: September 21, $2021 \quad$ Online Published: October 15, 2021

doi:10.5539/jas.v13n11p41

URL: https://doi.org/10.5539/jas.v13n11p41

\begin{abstract}
Mycorrhizal association contributes to plant growth, influencing tolerance to abiotic stresses such as water deficit. There is considerable variation in infection by arbuscular mycorrhizal fungi (AMF) in cultivars of the same crop, but there is little information regarding these differences in wheat. The objective of this work was to evaluate the influence of water deficit on the arbuscular mycorrhizal association in wheat genotypes in the Cerrado region and the association between soil attributes and mycorrhizal colonization. The experiment was conducted in a no-till system, using different water regimes. The experimental design was a randomized block with subdivided plots scheme, with 12 treatments and 3 repetitions. The plots consisted of 4 wheat genotypes and the subplots included 3 water regimes. Mycorrhizal colonization, soil microbial biomass carbon, total soil organic carbon, easily extractable glomalin-related soil protein, spore number and AMF species diversity were evaluated. Mycorrhizal colonization was not influenced by wheat genotypes, but it was favored by the higher water regime, being $44.8 \%$ higher when compared to the lower water regime. The soil moisture was positively correlated with the soil attributes with the exception of the number of AMF spores. The community of AMF associated with wheat genotypes was similar, comprising of 12 species, predominantly Claroideoglomus etunicatum and Glomus macrocarpum. The low variation among wheat genotypes for AMF diversity suggests no selective influence of the plants on the AMF community in the area of the study. Water regime was shown to be a dominant factor in mycorrhizal association.
\end{abstract}

Keywords: soil attributes, Cerrado, water deficit, arbuscular mycorrhizal fungi, no-till, Triticum aestivum

\section{Introduction}

Water availability is one of the environmental variables that are crucial for agricultural production. This resource is at the center of the concerns of farmers, since climate change projections point to an increase in the number of consecutive days of drought, with possible effects in the regions with the highest water demand for agriculture, such as the Brazilian Cerrado (Avila-Diaz et al., 2020). This region is home to $43 \%$ of the area of grain crops in Brazil (CONAB, 2021), but developing strategies capable of overcoming the cultivation limits in the winter period due to low rainfall represents an important possibility to increase production without expanding the area already cultivated. In non-irrigated systems, these strategies can collaborate to the implementation of the so-called "safrinha" crop, which occurs exactly in periods of lower water availability.

Wheat (Triticum aestivum L.) is one of the most cultivated and consumed cereals in the world (Takeiti, 2015; Wang et al., 2012) and has been managed in non-irrigated systems during the period of greater rainfall availability in the Brazilian Cerrado. In the 2021 crop season, the total area planted in this region was of 106,600 hectares, which represented an increase of $84.7 \%$ from the previous harvest (CONAB, 2021). The occurrence of high rainfall in the summer period associated with favorable edaphic conditions (e.g., porous and deep soils, smooth topography and improved fertility), as well as the favorable geographical location for distribution and commercialization, has driven wheat cultivation in the region (Condé et al., 2009; Galindo et al., 2015). Breeding programs have been developed in the region seeking to adapt cultivars with lower water demand, with 
the purpose of enabling cultivation also in the period of greater irregularity in the amount and distribution of rainfall (Soares et al., 2021).

Associated with breending programs, the selection of cultivars capable of symbiosis with arbuscular mycorrhizal fungi (AMF) may be important due to the recognized contribution of these fungi in the ability of cultivated plants to tolerate periods of reduced rainfall (Bernardo et al., 2019). This contribution is related to the greater water uptake area by the extraradicular hyphae of AMF, with facilitated access to soil micropores that results in greater water flux in the apoplasm (Bárzana et al., 2012a; Chitarra et al., 2016). AMF also stimulate root exudation, especially from the release of glomalin, resulting in increased soil aggregation in the rhizosphere, minimizing the negative effects promoted by rainfall shortages (Cheng et al., 2021). Arbuscular mycorrhizal association also favors microbial biomass and soil carbon accumulation (Vlček \& Pohanka, 2020). The composition of the AMF community influences the functionality of symbiosis in different ecosystems, such as agroecosystems (Castillo et al., 2016), with limited knowledge on the relationship between the AMF community and the plants' response to symbiosis by assessing mycorrhizal colonization (Léon et al., 2020).

The benefits arising from mycorrhizal association for cultivated plants are of great interest for sustainable agricultural production and are directly regulated by environmental conditions, with agricultural management practices being considered as the main regulator (Barea, 2015). Variations in AMF infection among cultivars have been reported in the literature (Lehnert et al., 2017; Nahar et al., 2020). The selection of wheat cultivars with higher capacity of association with AMF may be important to determine the most suitable materials for cultivation in the Brazilian Cerrado during the period of lower rainfall occurrence. Keeping this in view, the objective of the present work was to evaluate the influence of dryland wheat genotypes submitted to water stress on the dynamics of arbuscular mycorrhizal symbiosis under field conditions in the Brazilian Cerrado and the association between soil attributes and mycorrhizal colonization.

\section{Material and Methods}

\subsection{Characterization and History of the Experimental Area}

The experiment was conducted between June and September of 2016, in the experimental field of Embrapa Cerrados, in Planaltina, DF. The experimental field was located in the following geographical coordinates: latitude $15^{\circ} 35^{\prime} 30^{\prime \prime}$ South and longitude $47^{\circ} 42^{\prime} 30^{\prime \prime}$ West, altitude $1000 \mathrm{~m}$, on a typical dystrophic Red Latosol with clayey texture (Soil Survey Staff, 2010).

The climate of the region, according to the Köppen classification, is seasonal tropical Aw type with two well-defined seasons: a dry period in the fall and winter; a rainy period in the spring and summer with possible occurrences of "veranicos"1. The average annual temperature is $20.5^{\circ} \mathrm{C}$ with precipitation of $1538 \mathrm{~mm}$ (Figure $1)$.

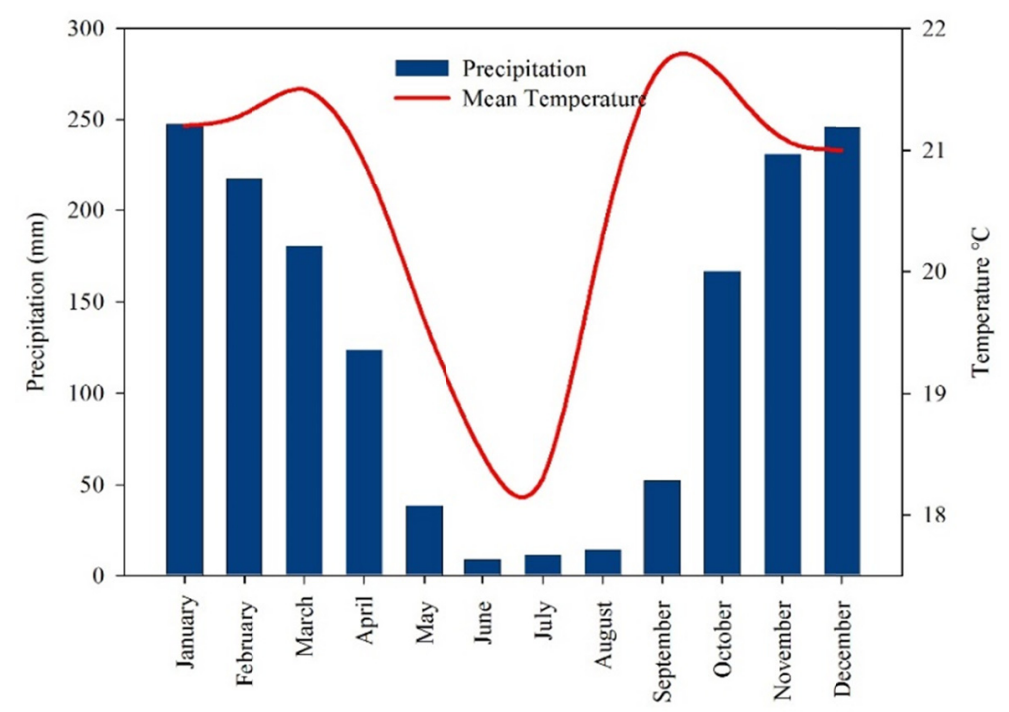

Figure 1. Climatological data of average temperature and accumulated monthly precipitation of the Federal District region (Climatological Normal 1961-1990)

Source: INMET (2019). 
The area was cultivated with wheat in a no-till system for 10 years with the same cultivars selected for this study in winter (May to September), and in summer (October to April), soybean-bean rotation was performed. The chemical characterization of the soil in the $0-20 \mathrm{~cm}$ layer, sampled before the experiment was set up was: $\mathrm{pH}$ $\left(\mathrm{H}_{2} \mathrm{O}\right)=6.36$; Organic matter $=21.6 \mathrm{~g} \mathrm{dm}^{-3}, \mathrm{P}($ Melich-1 $)=7.23 \mathrm{mg} \mathrm{dm}^{-3} ; \mathrm{K}, \mathrm{Ca}, \mathrm{Mg}, \mathrm{H}+\mathrm{Al}$ and CTC: 0.35 ; $3.01 ; 1.72 ; 3.47$ and $8.55 \mathrm{cmol}_{\mathrm{c}} \mathrm{dm}^{-3}$, respectively.

\subsection{Experimental Design and Execution of the Experiment}

The experimental design was a randomized block with subdivided plots scheme, with 12 treatments and 3 repetitions. The plots were composed of four rainfed wheat genotypes and the subplots were composed of three water regimes.

The wheat genotypes used were: (1) BRS 404: Dryland material, tolerant to drought, heat, and toxic soil aluminum. Bread-type commercial grade. Obtained from crossing the Aliança cultivar and the WT 99172 strain (Silva et al., 2015); (2) Brilhante: dryland material, tolerant to drought, bread-type commercial class. It was obtained from the PF 8640 strain and the BR 24 cultivar. It presents abundant root system, a desirable characteristic for the efficient use of water under conditions of hydric deficiency (Franco \& Evangelista, 2018); (3) PF 020037: strain selected under dryland conditions. It presents intense waxiness in the leaves and stems, a natural mechanism for drought tolerance; 4) PF 080492: dryland material from the southern region of the country, however it adapted well in the Midwest region.

The subplots consisted of variable water regimes, lower than the replenishment of crop evapotranspiration (ETc). Irrigations were performed as described in the Brazilian Cerrado irrigation monitoring program (Embrapa, 2011), by replacing evapotranspiration, using agrometeorological indicators of the region, the soil type and the date of full emergence of the plants. Three water regimes corresponding to 96,68 and $6 \%$ of ETc replacement were considered (L96, L68 and L6). The variable water regimes were obtained by adapting an irrigation bar with a set of sprinklers with different flow rates, in a declining pattern. It was coupled with a reel with adjustable speed in order to apply the desired volumes (Hanks et al., 1976).

The sowing occurred on June 1, 2016, and the useful area of each plot (wheat genotypes) was of $18 \mathrm{~m}^{2}(18 \mathrm{~m}$ long by $1 \mathrm{~m}$ wide). They were installed perpendicular to the irrigation bar. The subplots consisted of $1 \mathrm{~m}^{2}(1 \mathrm{~m}$ long by $1 \mathrm{~m}$ wide) located in the position of the water regime adopted within each plot. The plant density was of 350 plants $\mathrm{m}^{-2}$.

Prior to the experiment setup, the soil was treated with glyphosate herbicide to control weeds. According to the chemical analysis of the soil, the fertilizer recommendation at planting was of $441 \mathrm{~kg} \mathrm{ha}^{-1}$ of mixed mineral fertilizer 04-30-16. At the beginning of the crop tillering, nitrogen fertilization was performed with $100 \mathrm{~kg} \mathrm{ha}^{-1}$ of nitrogen in the form of urea. Thirty days after emergence, the treatments received an application of $0.5 \mathrm{~L} \mathrm{ha}^{-1}$ of trinexapaque-ethyl as a growth regulator.

Until 30 days after planting, the plots received the same water volume, accumulating $134.1 \mathrm{~mm}$ (including precipitation). After this time, on the 35th day after planting, irrigation began with variable water regimes, using irrigation bars with different flow rates. Fourteen irrigations were applied at different volumes according to the corresponding treatments (L96, L68 and L6) until the end of the crop cycle (Figure 2). 


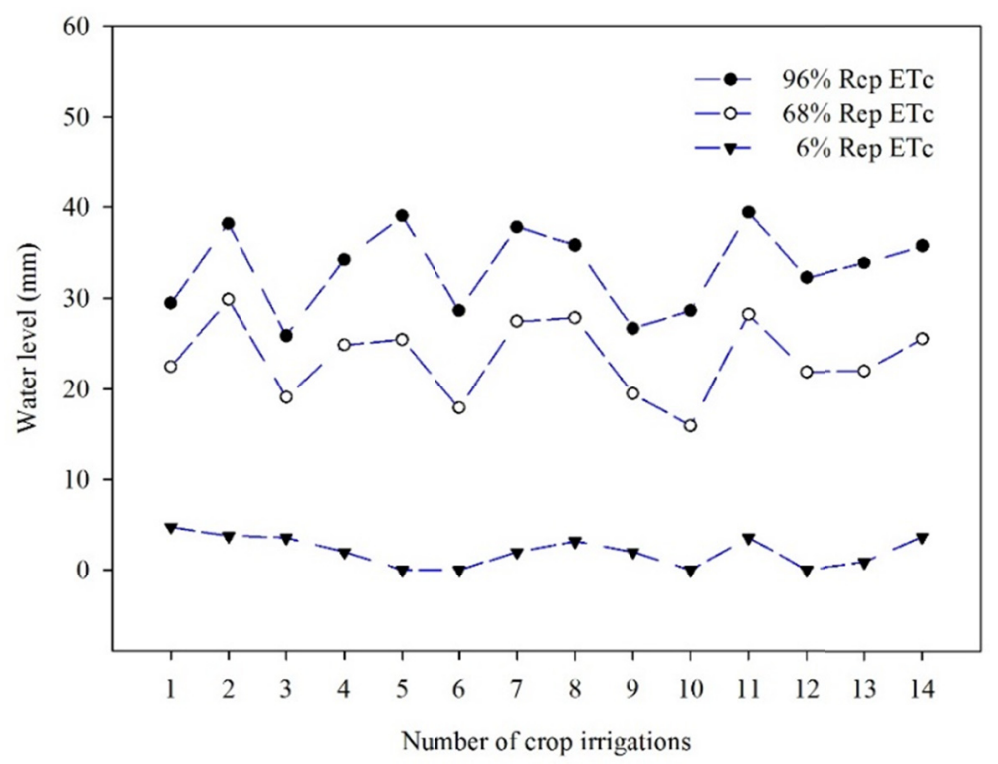

Figure 2. Water regimes applied during the period between days 35 and 71 after planting, based on the crop evapotranspiration replenishment (Rep ETc) in different hydric regimes and different wheat genotypes in a Red Latosol in the Brazilian Cerrado

On average, the water regimes applied during this period were of 33, 23 and $2 \mathrm{~mm}$ for L96, L68 and L6 respectively, accumulating a total volume of 599, 462 and $164 \mathrm{~mm}$ for the total crop cycle (Figure 3).

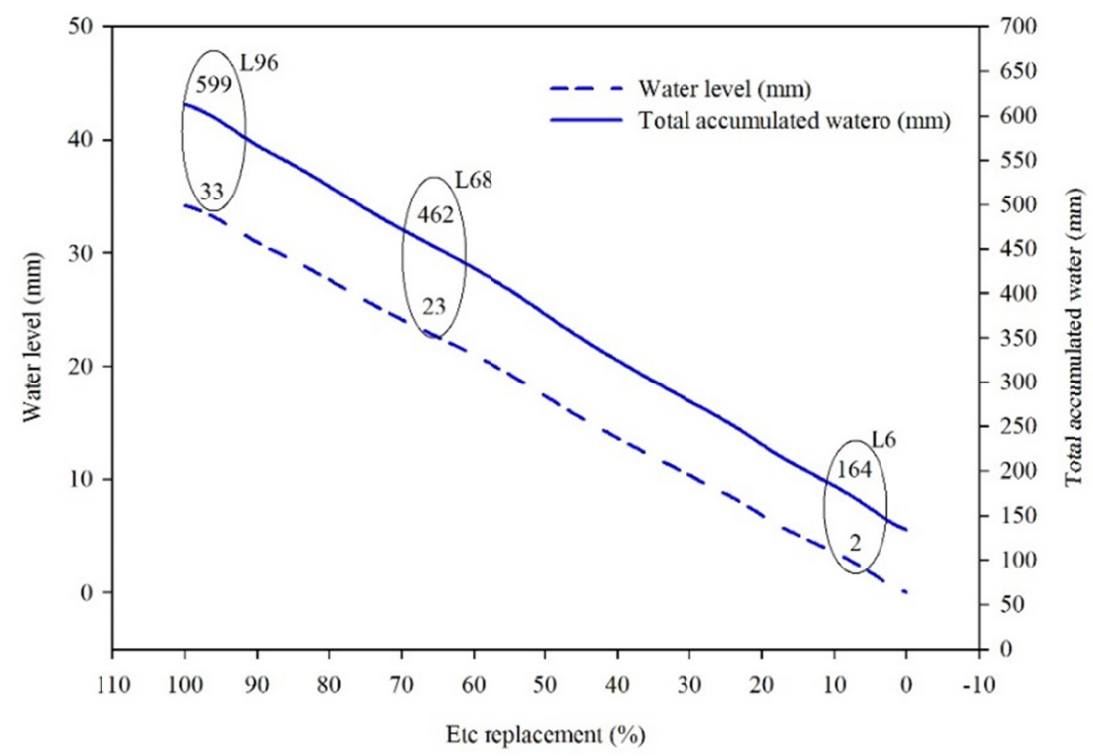

Figure 3. Diagram representing the average applied volumes and total accumulated volume during the cycle of different wheat genotypes on a Red Latosol in the Brazilian Cerrado

The monitoring of the volumes applied after each irrigation was performed by distributing plastic collectors installed perpendicular to the irrigation bar. With this, we determined the actual volumes $(\mathrm{mm})$ applied in the treatments at each irrigation.

\subsection{Collection and Analyzed Variables}

Approximately 72 days after seedling emergence, during the flowering period, soil and root samples were collected. Soil was collected in the rows of the planting, in the $0-10 \mathrm{~cm}$ layer, in a composite sample of five sub-samples. The wheat roots were collected from 5 random plants within each experimental plot. The materials 
were immediately sent to the laboratory, the soil samples were kept in a cold chamber at $4^{\circ} \mathrm{C}$ and the roots were kept in a $70 \%$ alcohol solution. A portion of the soil samples was used immediately after collection for moisture determination using the gravimetric method (Black, 1965).

Soil microbial biomass carbon (MBC) was determined using the fumigation-extraction method proposed by Vance et al. (1987). For this, the samples were incubated at $80 \%$ of field capacity for 7 days and, after this period, half of the samples were fumigated with $\mathrm{CHCl}_{3}$ for $24 \mathrm{~h}$. A solution of $\mathrm{K}_{2} \mathrm{SO}_{4} 0.5 \mathrm{~mol} \mathrm{~L}^{-1}$ was used as extraction solution and the oxidation of organic carbon employed $\mathrm{K}_{2} \mathrm{Cr}_{2} \mathrm{O}_{7} 0.40 .166 \mathrm{~mol} \mathrm{~L}^{-1}$ solution in acidic medium. The amount of $\mathrm{MBC}$ was determined by the difference between the carbon extracted from fumigated and non-fumigated soil, using the correction factor $\mathrm{kec}=0.379$, according to Vance et al. (1987).

Total soil organic carbon (TOC) was determined according to the methodology described by Walkley and Black (1934), by oxidation with $\mathrm{K}_{2} \mathrm{Cr}_{2} \mathrm{O}_{7} 0.166 \mathrm{~mol} \mathrm{~L}^{-1}$ and titration of the remaining $\mathrm{Cr}^{6-}$ with $\mathrm{Fe}\left(\mathrm{NH}_{4}\right)_{2}\left(\mathrm{SO}_{4}\right)_{2} \cdot 6 \mathrm{H}_{2} \mathrm{O}$ approximately $0.5 \mathrm{~mol} \mathrm{~L}^{-1}$.

The determination of easily extractable glomalin-related soil protein concentration (GRSP-EE) was performed according to the methodology described by Wright and Upadhyaya (1996), from extraction of $1 \mathrm{~g}$ of TFSA (air-dried fine soil) with $8 \mathrm{~mL}$ of $\mathrm{Na}_{3} \mathrm{C}_{6} \mathrm{H}_{5} \mathrm{O}_{7} 20 \mathrm{mmol} \mathrm{L}^{-1}$, at $\mathrm{pH} 7.0$, at $121{ }^{\circ} \mathrm{C}$, for 30 minutes. The samples were centrifuged (5000 rpm, $10 \mathrm{~min}$ ) and the concentration of GRSP-EE in the supernatant was determined by the Bradford essay (1976) on optical density of $595 \mathrm{~nm}$ using bovine serum albumin (BSA) as the standard protein.

The rate of mycorrhizal colonization was evaluated by bleaching the roots and staining the fungal structures according to Phillps and Hayman (1970). The bleaching was performed with $\mathrm{KOH} 0.1 \mathrm{~mol} \mathrm{~L}^{-1}$, in water bath, followed by the staining of the AMF structures with trypan blue solution. To determine the colonization rate, a grid plate and stereoscopic microscope were used, according to Giovannetti and Mosse (1980).

The number of AMF spores in the soil was determined by the wet sieving method proposed by Gerdemann and Nicolson (1963), with a few adaptations. To recover the largest number of spores retained in the soil aggregates, the soil sample $\left(50 \mathrm{~cm}^{3}\right)$ was shaken in a blender with tap water for 30 seconds and, after soil decantation, the suspension was disposed on sieves with 1000 and $45 \mu \mathrm{m}$ mesh. The material retained on the $45 \mu \mathrm{m}$ sieve was placed in centrifuge tubes with water and centrifuged $(3000 \mathrm{rpm}, 3 \mathrm{~min})$. The supernatant was discarded, and a new centrifugation ( $2000 \mathrm{rpm}, 3 \mathrm{~min}$ ) was performed with $50 \%$ sucrose solution. The supernatant was recovered for spore counting using a channel plate and stereoscopic microscope.

Taxonomic identification of AMF species was performed through morphological characterization (color, shape, size, among other characteristics) of the healthy spores extracted from the spore density analysis. Permanent slides were made in PVLG (Polyvinyl-Lactoglycerol) and PVLG + Melzer's reagent medium. The identification of AMF species was conducted with the help of the database provided by the International Collection of Arbuscular and Vesicular-Arbuscular Mycorrhizal Fungal Cultures of West Virginia University (INVAM, 2021) and the Department of Plant Pathology of the Agricultural University of Szczcin Poland (Janusz, 2019), both available on their corresponding websites.

\subsection{Statistical Analysis}

The data were submitted to variance analysis and the means were compared using Tukey's test $(\mathrm{p} \leq 0.05)$ with the Sisvar 5.6 statistics software (Ferreira, 2010). The spore number and mycorrhizal colonization data were transformed in $\log X+1$ and $(\operatorname{arc} \operatorname{sen} \% / 100) \times 0.5$, respectively.

\section{Results}

\subsection{Soil Microbiological Attributes and Mycorrhizal Symbiosis}

The cultivation of the different wheat genotypes resulted in similar effect on MBC, TOC, GRSP-EE contents, mycorrhizal colonization and AMF spore density (Table 1). However, the water regimes affected the contents of MBC, TOC, GRSP-EE and mycorrhizal colonization. In relation to the water regimes, the highest averages for MBC (284 mg kg $\left.{ }^{-1}\right)$, TOC (21 mg kg-1), GRSP-EE $\left(6 \mathrm{mg} \mathrm{g}^{-1}\right)$ and colonization rate (42\%) were observed in treatment L96. 
Table 1. Microbial biomass carbon (MBC); total organic carbon (TOC); easily extractable soil protein related to glomalin (GRSP-EE); mycorrhizal colonization rate (MC) and number of spores (Spores) in a red Latosol with different wheat genotypes and water regimes, in the $0-10 \mathrm{~cm}$ layer

\begin{tabular}{llllll}
\hline Wheat genotypes & MBC & TOC & GRSP-EE & MC & Spores \\
\hline & $\mathrm{mg} \mathrm{kg}^{-1}$ solo & $\mathrm{g} \mathrm{kg}^{-1}$ solo & $\mathrm{mg} \mathrm{g}^{-1}$ solo & $\%$ & $\mathrm{n}^{\mathbf{0}} 50 \mathrm{~cm}^{-3}$ \\
Brilhante & 236 & 19 & 4.9 & 32 & 190 \\
BRS 404 & 223 & 20 & 4.6 & 35 & 241 \\
PF 020037 & 261 & 20 & 5.0 & 33 & 281 \\
PF 080492 & 208 & 19 & 4.6 & 37 & 296 \\
L96 & $284 \mathrm{a}$ & $21^{\mathrm{a}}$ & $6.0 \mathrm{a}$ & $42 \mathrm{a}$ & 224 \\
L68 & $220 \mathrm{~b}$ & $20 \mathrm{~b}$ & $4.6 \mathrm{~b}$ & $33 \mathrm{ab}$ & 239 \\
L6 & $191 \mathrm{~b}$ & $19 \mathrm{~b}$ & $3.6 \mathrm{c}$ & $29 \mathrm{~b}$ & 294 \\
\hline CV1 (\%) & 25 & 9 & 19 & 14 & 54 \\
CV2 (\%) & 28 & 7 & 13 & 18 & 62 \\
\hline
\end{tabular}

Note. The means followed by the same letter in the column do not statistically differ using Tukey's test ( $\mathrm{p} \leq 0.05)$. CV1: coefficient of variation related to the wheat genotypes; CV2: coefficient of variation related to the water regimes. L96, L68, and L6 correspond to the volumes 96, 68, and 6\% of ETc replenishment, respectively. Data transformed into $(\log X+1)$ for spore density and $(\operatorname{arc}$ sen $\% / 100) \times 0.5$ for mycorrhizal colonization rate.

On water regimes L68 and L6, a significant reduction in MBC contents on the order of 22.5 and $32.7 \%$, respectively, compared to L96, was observed. For TOC, reductions of 5 and 9.5\% were observed at L68 and L6, compared to L96. GRSP-EE contents were reduced by 23.3 and $40 \%$ in L68 and L6, respectively, while mycorrhizal colonization rates were reduced by 21.4 and $30.9 \%$. Soil moisture positively influenced the increase in the contents of the soil attributes evaluated, except for the number of AMF spores (Table 2). GRSP-EE was the attribute that had the highest correlation with soil moisture $\left(0.721^{* *}\right)$.

Table 2. Pearson's correlation in the attributes of a Red Latosol with different wheat genotypes and water regimes, in the $0-10 \mathrm{~cm}$ layer

\begin{tabular}{lllllll}
\hline & Soil Moisture & MBC & TOC & GRSP-EE & MC & Spores \\
\hline Soil Mosture & 1 & $0.470^{* *}$ & $0.497^{* *}$ & $0.721^{* *}$ & $0.473^{* *}$ & -0.177 \\
MBC & & 1 & $0.401^{* *}$ & $0.380^{* *}$ & 0.068 & -0.160 \\
TOC & & 1 & $0.524^{* *}$ & 0.224 & -0.019 \\
GRSP-EE & & & 1 & $0.453^{* *}$ & -0.185 \\
MC & & & & 1 & $-0.277^{*}$ \\
Spores & & & & & 1 \\
\hline
\end{tabular}

Note. MBC = Microbial biomass carbon; TOC = Total organic carbon; GRSP-EE = Glomalin-related soil protein-easily extractable; $\mathrm{MC}=$ Mycorrhizal colonization.

\subsection{Occurrence and Distribution of Arbuscular Mycorrhizal Fungi Species}

Twelve species of AMF were observed in the obtained samples, ten of which could be identified at species level and two at genus level. The species that occurred in all experimental plots were Claroideoglomus etunicatum and Glomus macrocarpum (Table 3), both with higher frequency of spores (100\%). The species Ambispora leptoticha, Scutellospora gregaria and Gigaspora sp. had the lowest spore frequency values (42, 50 and 50\%, respectively). The species Acaulospora mellea, Acaulospora rehmii, Acaulospora scrobiculata, Glomus clavisporum, Glomus microagregatum, Glomus sp. and Scutellospora cerradencis were also identified, showing varying occurrences in the studied areas.

In the plots cultivated with the genotype Brilhante, the species Acaulospora rehmii, Glomus sp. and Gigaspora sp. were observed only at the lowest water regime (L6), and the species Acaulospora mellea and Ambispora leptoticha only at the intermediate water regime (L68). Of the 12 species identified, 5 were present at all water regimes (Claroideoglomus etunicatum, Glomus macrocarpum, Acaulospora scrobiculata, Glomus clavisporum and Scutellospora gregaria). 
Among the wheat genotypes, only in the genotype PF 020037, the influence of only one of the water regimes (L6) was found in the specific presence of the species Ambispora leptoticha, Scutellospora gregaria and Scutellospora cerradencis. On the other hand, for this same genotype, Claroideoglomus etunicatum, Glomus clavisporum, Glomus macrocarpum and Gigaspora sp. were found in all water regimes.

In the plots cultivated with the BRS 404 genotype, the species Glomus clavisporum was observed only at the lowest water regime (L6) and the species Acaulospora mellea only at the highest one (L96). Like the areas cultivated with the other genotypes, the species Claroideoglomus etunicatum and Glomus macrocarpum were observed in all the water regimes.

In the plots cultivated with the genotype PF 080492, the species Glomus microagregatum and Gigaspora sp. were observed only at the intermediate water regime (L68) and the species Ambispora leptoticha was observed only at the highest one (L96). Similar to the areas cultivated with the genotype Brilhante, five of the 12 identified species were present in all the water regimes (Acaulospora mellea, Acaulospora scrobiculata, Claroideoglomus etunicatum and Glomus macrocarpum).

Considering the influence of the water regimes on the distribution of AMF species, the presence of the 12 identified species was observed in at least one of the wheat genotypes. In treatment L6, the greatest number of the most frequent species was found, which were Acaulospora scrobiculata, Claroideoglomus etunicatum, Glomus clavisporum and Glomus macrocarpum. Glomus microagregatum was the species with the lowest frequency, found only in the subplot cultivated with the genotype BRS 404.

The species with higher frequency in the intermediate water regime (L68) were similar to those observed in treatment L6, except for Glomus clavisporum. Two species presented the lowest frequency: Ambispora leptoticha and Scutellospora gregaria, both occurred only in the subplot cultivated with the genotype Brilhante.

In treatment L96, only Claroideoglomus etunicatum and Glomus macrocarpum species presented higher frequency, also observed in the other water regimes. The species that presented the lowest frequency was Gigaspora sp. found only in the subplot cultivated with genotype PF020037.

Table 3. Diversity of morphologically identified AMF species of a red Latosol with different wheat genotypes and water regimes at a depth of $0-10 \mathrm{~cm}$

\begin{tabular}{|c|c|c|c|c|c|c|c|c|c|c|c|c|c|}
\hline \multirow{3}{*}{ FMA Species } & \multicolumn{12}{|c|}{ Wheat genotypes/Water regime } & \multirow{3}{*}{$\begin{array}{l}\text {-Frequency } \\
-(\%)\end{array}$} \\
\hline & \multicolumn{4}{|c|}{ L6 } & \multicolumn{4}{|c|}{ L68 } & \multicolumn{4}{|c|}{ L96 } & \\
\hline & Brilhante & PF020037 & BRS404 & PF080492 & Brilhante & PF020037 & BRS404 & PF080492 & Brilhante & PF020037 & BRS404 & PF080492 & \\
\hline Acaulospora mellea & & + & & + & + & & & + & & + & + & + & 58 \\
\hline Acaulospora rehmii & + & & + & + & & + & & + & & + & + & & 58 \\
\hline Acaulospora scrobiculata & + & + & + & + & + & + & + & + & + & + & & + & 92 \\
\hline Ambispora leptoticha & & + & + & & + & & & & & & + & + & 42 \\
\hline Claroideoglomus etunicatum & $n+$ & + & + & + & + & + & + & + & + & + & + & + & 100 \\
\hline Glomus clavisporum & + & + & + & + & + & + & & + & + & + & & + & 83 \\
\hline Glomus macrocarpum & + & + & + & + & + & + & + & + & + & + & + & + & 100 \\
\hline Glomus microagregatum & & & + & & + & + & & + & + & + & + & & 58 \\
\hline Glomus sp. & + & + & & + & & + & + & + & & & + & & 58 \\
\hline Scutellospora gregaria & + & + & + & & + & & & & + & & + & & 50 \\
\hline Scutellospora. cerradencis & + & + & & & + & & + & + & & & + & + & 58 \\
\hline Gigaspora sp. & + & + & & & & + & + & + & & + & & & 50 \\
\hline Species richness & 10 & 11 & 9 & 8 & 11 & 10 & 8 & 12 & 9 & 11 & 12 & 10 & \\
\hline
\end{tabular}

Canonical correspondence analysis confirmed that the occurrence and spore frequency of the identified species were not influenced by wheat genotypes (Table 1), but by water regimes (Figure 4). The higher water regime favored the diversity of AMF. It is important to emphasize that the number of spores does not indicate the number of individuals of the identified species, since spores are only a reproduction structure of AMF. In this sense, although the number of recovered spores has an inverse relationship with mycorrhizal colonization, the increase in PSRG-FE contents and the greater diversity of AMF indicate that there is a greater activity in environments with greater soil moisture, as observed in the highest water regime. 


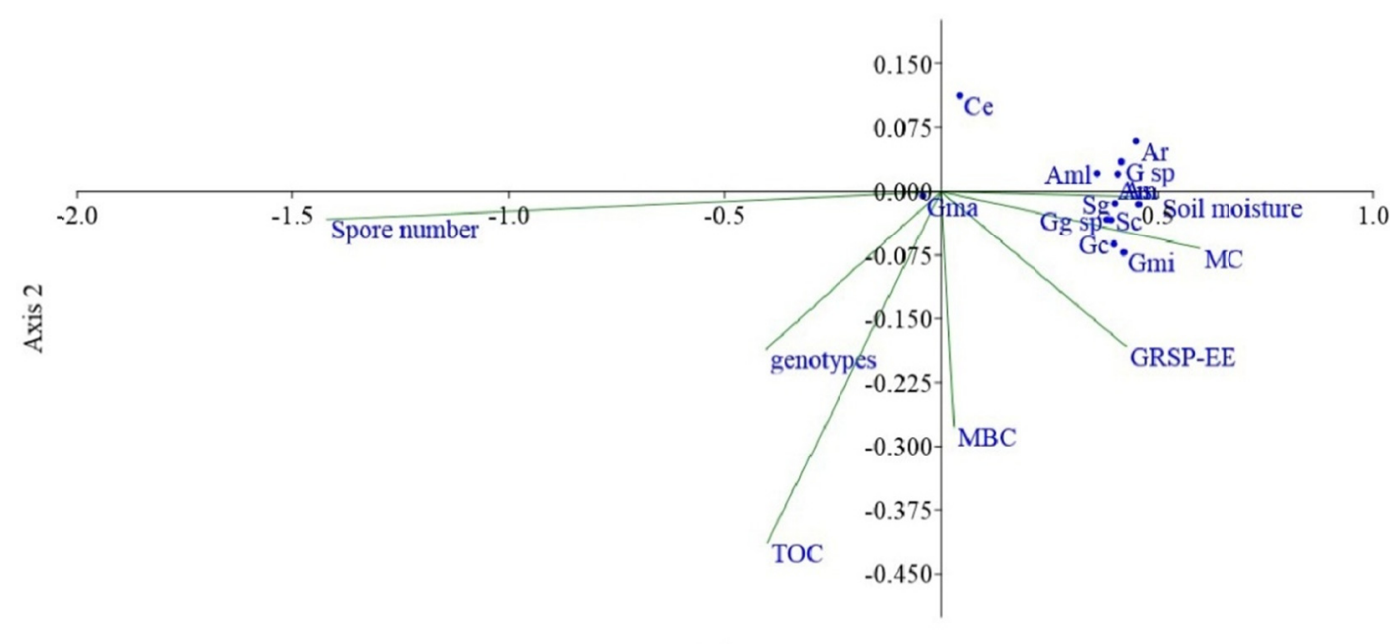

Axis 1

Figure 4. Canonical correspondence analysis of the frequency of spores of arbuscular mycorrhizal fungi species and soil attributes in a red Latosol with different wheat genotypes and water regimes, in the 0-10 cm layer. Am $=$ Acaulospora mellea $; \mathrm{Ar}=$ Acaulospora rehmii $; \mathrm{As}=$ Acaulospora scrobiculata $; \mathrm{Aml}=$ Ambispora leptoticha $;$ $\mathrm{Ce}=$ Claroideoglomus etunicatum $; \mathrm{Gc}=$ Glomus clavisporum $; \mathrm{Gma}=$ Glomus macrocarpum $; \mathrm{Gmi}=$ Glomus microagregatum; $\mathrm{G}$ sp. = Glomus $\mathrm{sp} . ; \mathrm{Sg}=$ Scutellospora gregaria; $\mathrm{Sc}=$ Scutellospora cerradencis; $\mathrm{Gg} \mathrm{sp}=$ Gigaspora sp. $\mathrm{TOC}=$ total organic carbon; $\mathrm{MBC}=$ microbial biomass carbon; GRSP-EE $=$ glomalin-related soil protein-easily extractable; Genotytes $=$ Brilhante, PF020037. BRS404, PF080492; MC $=$ mycorrhizal colonization; spore number $=\mathrm{AMF}$ spore number; soil moisture

\section{Discussion}

\subsection{Soil Microbiological Attributes and Mycorrhizal Symbiosis}

The survival of microorganisms and their activity are dependent on the availability of water in the soil. MBC responds to climatic conditions, and intensified water stress reduces MBC content (Geng et al., 2015). MBC contents below $245 \mathrm{mg} \mathrm{kg}^{-1}$ are considered low (Mendes et al., 2019) and associated with severe drought conditions (Geng et al., 2015), as was observed at water regimes L68 and L6.

Low soil water availability also affects the carbon flux between plants and soil by causing stomatal closure and subsequent decline in transpiration, as well as reduced photosynthesis and, consequently, decreased plant-derived TOC and rhizodeposition (Zhao et al., 2020). Other studies also show that water-deficit environments severely reduce soil carbon deposition, also affecting the contents of TOC (Hasibeder et al., 2015; Canarini \& Dijkstra, 2015; Fuchslueger et al., 2016).

Wheat genotypes did not influence MBC and TOC contents. Morphological characteristics such as root to aerial part ratio and root thickness (data not evaluated) assist in understanding the contribution of plants to the allocation of soil carbon by rhizodeposition (Bakhshandeh et al., 2018). Unlike the findings in this study, wheat genotypes with higher root to aerial part ratio and thicker roots allocated more carbon in the soil through rhizodeposition at the expense of producing higher yield (Bakhshandeh et al., 2018), and these traits may play an important functional role in transferring more carbon to the soil TOC pool.

An essential component of TOC in terrestrial ecosystems (Jia et al., 2016) and a participant in soil stored carbon (Wilkes et al., 2021), GRSP-EE correlated positively with TOC and stands out as an essential component for TOC in terrestrial ecosystems (Jia et al., 2016). A positive correlation was also found for GRSP-EE and MBC in wheat areas cultivated under different management systems under temperate climate condition (Galazka et al., 2018).

The water restriction resulting from the application of the smallest water regime (L6) reduced the content of GRSP-EE in the soil and the CM, possibly due to unfavorable conditions for plant root growth (data not evaluated) and, consequently resulting in limitation in the development of mycorrhizal symbiosis, abundance and diversity of AMF. Different AMF species produce different amounts of glomalin and only these fungi produce PSRG; therefore, a diverse and abundant AMF community contributes to higher glomalin contents in the soil 
(Hossain, 2021). This relationship is based on experiments with AMF colonized and non-colonized root samples, where glomalin was only detected in roots colonized by these fungi (Vlček \& Pohanka, 2020).

In accordance with the results observed in this work, the CM at the highest water regimes (L96 and L68) is similar in wheat grown under different management systems, under temperate climate condition (Galazka et al., 2018) and is also within the average observed (41\%) in a study that evaluated CM in 94 wheat genotypes (Lehnert et al., 2017).

Management practices that interfere with plant development, such as fertilization, use of pesticides, monocultivation, and constant soil disturbance, result in reduced presence of infective propagules of arbuscular mycorrhizae (Nyamwange et al., 2018), such as the number of AMF spores. In more conservationist systems, such as no-till, there is a favorable environmental condition for the development of symbiosis, due to the absence of soil disturbance (Schalamuk \& Cabello, 2010). In the area of the study, the adoption of no-till farming as a cropping system, coupled with a crop rotation program with grasses and legumes (Silva et al., 2020), possibly created favorable conditions for the preservation of the AMF spore numbers. In the symbiosis development cycle, the production of spores among AMF species have different timing and quantity of sporulation and germination (Gomide et al., 2009; Nyamwange et al., 2018), thus, the absence of response observed for the number of AMF spores may be related to the evaluation period used in this study (70 days after wheat plants emergence), and this can be considered a short period for observing the response to changes in soil management and environmental factors.

\subsection{Occurrence and Species Diversity of Arbuscular Mycorrhizal Fungi}

The higher irrigation increased the diversity of AMF, according to the canonical correspondence analysis (Figure 4). Favorable environmental conditions such as the availability of water for the host plant and, consequently, for the symbiont, are factors that contribute to the abundance of AMF species, while adverse conditions such as water scarcity act as an environmental filter and a reduced number of AMF that are tolerant to the predominant habitat are able to remain in the environment (Deepika \& Kothamasi, 2015). Studies have highlighted that changes in soil water availability can affect AMF community composition (Deveautour et al., 2018; Deepika \& Kothamasi, 2015). The influence of soil management practices such as irrigation on the composition of the AMF community in areas of annual crops is apparently dominant when compared to the plant community present in the experimental area (Bainard et al., 2017).

The predominance of species that belong to the families Glomeraceae, Acaulosporaceae and Gigasporaceae is consistent with the assessment of the AMF community in no-till areas cultivated with wheat (Schalamuk $\&$ Cabello, 2010). The two species with the highest frequency in the study area, Claroideoglomus etunicatum and Glomus macrocarpum (Table 3), have already been identified with higher occurrence in agricultural areas, in conventional and conservationist systems, as well as in native Cerrado areas (Fernandes et al., 2016; Ferreira et al., 2012; Nunes et al., 2019; Pontes et al., 2017). The high frequency of a species of the genus Claroideoglomus (Claroideoglomus claroideum) was reported in an area cultivated with wheat in southern Chile (Castillo et al., 2016). Among the less frequent species observed in this work (Ambispora leptoticha, Scutellospora gregaria and Gigaspora sp.), Ambispora leptoticha was also among the least frequent species in wheat-grown areas in southern Chile (Castillo et al., 2016).

The predominance of Glomus species (about $41 \%$ of the species identified in this work) in no-till areas is associated with the ability and evolutionary adaptation of AMF of this genus to use extraradicular hyphae and colonized root fragments as infective propagules, to the detriment of spore production (Schalamuk \& Cabello, 2010). The contribution in the tolerance of wheat plants to water stress is described among the benefits promoted by inoculation with a species belonging to the genus Glomus (Glomus mosseae), improving the yield and growth of plants under low water availability and controlled conditions (Rani et al., 2018).

\section{Conclusions}

The wheat genotypes studied, intended for breeding programs aiming at tolerance to water deficit, did not promote changes in the association with arbuscular mycorrhizal fungi and in the parameters of microbial biomass carbon, total organic carbon, soil protein relative to glomalin-easily extracted.

The association between soil attributes microbial biomass carbon, total organic carbon, soil protein relative to glomalin-easily extracted and mycorrhizal colonization in wheat plants were confirmed, contributing to studies concerning mycorrhizal symbiosis. 
The water regimes impacted the mycorrhizal colonization, as well as the soil parameters of microbial biomass carbon, total organic carbon, soil protein relative to glomalin-easily extractable, favored by the highest water regime, corresponding to $95 \%$ of the crop evapotranspiration.

The occurrence and frequency of arbuscular mycorrhizal fungal species, identified by morphological description, was favored by the water regimes and was not influenced by wheat genotypes.

\section{References}

Avila-Diaz, A., Benezoli, V., Justino, F., Torres, R., \& Wilson, A. (2020). Assessing current and future trends of climate extremes across Brazil based on reanalyses and earth system model projections. Climate Dynamics, 55(5-6), 1403-1426. https://doi.org/10.1007/s00382-020-05333-z

Bainard, L. D., Chagnon, P.-L., Cade-Menun, B. J., Lamb, E. G., LaForge, K., Schellenberg, M., \& Hamel, C. (2017). Plant communities and soil properties mediate agricultural land use impacts on arbuscular mycorrhizal fungi in the Mixed Prairie ecoregion of the North American Great Plains. Agriculture, Ecosystems \& Environment, 249, 187-195. https://doi.org/10.1016/j.agee.2017.08.010

Bakhshandeh, S., Corneo, P. E., Yin, L., \& Dijkstra, F. A. (2018). Drought and heat stress reduce yield and alter carbon rhizodeposition of different wheat genotypes. Journal of Agronomy and Crop Science, 205(2), 1-11. https://doi.org/10.1111/jac. 12314

Barea, J. M. (2015). Future challenges and perspectives for applying microbial biotechnology in sustainable agriculture based on a better understanding of plant-microbiome interactions. Journal of Soil Science and Plant Nutrition, 15(2), 261-282. https://doi.org/10.4067/s0718-95162015005000021

Bárzana, G., Aroca, R., Paz, J. A., Chaumont, F., Martinez-Ballesta, M. C., Carvajal, M., \& Ruiz-Lozano, J. M. (2012). Arbuscular mycorrhizal symbiosis increases relative apoplastic water flow in roots of the host plant under both well-watered and drought stress conditions. Annals of Botany, 109(5), 1009-1017. https://doi.org/10.1093/aob/mcs007

Bernardo, L., Carletti, P., Badeck, F. W., Rizza, F., Morcia, C., Ghizzoni, R., ... Lucini, L. (2019). Metabolomic responses triggered by arbuscular mycorrhiza enhance tolerance to water stress in wheat cultivars. Plant Physiology and Biochemistry, 137, 203-212. https://doi.org/10.1016/J.PLAPHY.2019.02.007

Black, C. A. (1965). Methods of Soil Analysis: Part I Physical and mineralogical properties. American Society of Agronomy, Madison, Wisconsin, USA. https://doi.org/10.2134/agronmonogr9.1

Bradford, M. M. (1976). A rapid and sensitive method for the quantitation of microgram quantities of protein utilizing the principle of protein-dye binding. Analytical Biochemistry, 72(1-2), 248-254. https://doi.org/10.1016/0003-2697(76)90527-3

Canarini, A., \& Dijkstra, F. A. (2015). Dry-rewetting cycles regulate wheat carbon rhizodeposition, stabilization and nitrogen cycling. Soil Biology and Biochemistry, 81, 195-203. https://doi.org/10.1016/j.soilbio. 2014.11.014

Castillo, C. G., Borie, F., Oehl, F., \& Sieverding, E. (2016). Arbuscular mycorrhizal fungi biodiversity: prospecting in Southern-Central zone of Chile. A review. Journal of Soil Science and Plant Nutrition, 16(2), 400-422. https://doi.org/10.4067/S0718-95162016005000036

Cheng, H. Q., Giri, B., Wu, Q. S., Zou, Y. N., \& Kuča, K. (2021). Arbuscular mycorrhizal fungi mitigate drought stress in citrus by modulating root microenvironment. Archives of Agronomy and Soil Science, 1-5. https://doi.org/10.1080/03650340.2021.1878497

Chitarra, W., Maserti, B., Gambino, G., Guerrieri, E., \& Balestrini, R. (2016). Arbuscular mycorrhizal symbiosis-mediated tomato tolerance to drought. Plant Signaling \& Behavior, 11(7), e1197468. https://doi.org/10.1080/15592324.2016.1197468

CONAB (Companhia Nacional de Abastecimento). (2021). Trigo: Projeção de crescimento em todo o Brasil. Retrieved from https://www.conab.gov.br/info-agro/safras/graos

Condé, A. B. T., Coelho, M. A. de O., Yamanaka, C. H., \& Corte, H. R. (2009). Adaptabilidade e estabilidade de genótipos de trigo sob cultivo de sequeiro em Minas Gerais. Pesquisa Agropecuária Tropical, 40(1), 45-52. https://doi.org/10.5216/pat.v40i1.5618

Deepika, S., \& Kothamasi, D. (2014). Soil moisture-A regulator of arbuscular mycorrhizal fungal community assembly and symbiotic phosphorus uptake. Mycorrhiza, 25(1), 67-75. https://doi.org/10.1007/s00572014-0596-1 
Deveautour, C., Donn, S., Power, S. A., Bennett, A. E., \& Powell, J. R. (2018). Experimentally altered rainfall regimes and host root traits affect grassland arbuscular mycorrhizal fungal communities. Molecular Ecology, 27(8), 2152-2163. https://doi.org/10.1111/mec.14536

Embrapa (Empresa Brasileira de Pesquisa Agropecuária). (1997). Manual de Métodos de Análise de Solo (2nd ed.). Rio de Janeiro, RJ: Embrapa-CNPS.

Embrapa (Empresa Brasileira de Pesquisa Agropecuária). (2011). Programa de Monitoramento de Irrigação no Cerrado. Retrieved from http://hidro.cpac.embrapa.br

Fernandes, R. A., Ferreira, D. A., Saggin-Junior, O. J., Stürmer, S. L., Paulino, H. B., Siqueira, J. O., \& Carneiro, M. A. C. (2016). Occurrence and species richness of mycorrhizal fungi in soil under different land use. Canadian Journal of Soil Science, 96(3), 271-280. https://doi.org/10.1139/cjss-2015-0011

Ferreira, D. A., Carneiro, M. A. C., \& Saggin-Junior, O. J. (2012). Arbuscular mycorrhizal fungi in an oxisol under managements and uses in cerrado. Revista Brasileira de Ciencia Do Solo, 36(1), 51-61. https://doi.org/10.1590/S0100-06832012000100006

Ferreira, D. F. (2010). Sisvar: A Guide for its Bootstrap procedures in multiple comparisons. Ciência e Agrotecnologia, 35(6), 1039-1042. https://doi.org/10.1590/S1413-70542011000600001

Franco, F. de A., \& Evangelista, A. (2018). Informações técnicas para trigo e triticale-Safra 2018/XI Reunião da Comissão Brasileira de Pesquisa de Trigo e Triticale. Londrina, PR: Embrapa Soja.

Fuchslueger, L., Bahn, M., Hasibeder, R., Kienzl, S., Fritz, K., Schmitt, M., ... Richter, A. (2016). Drought history affects grassland plant and microbial carbon turnover during and after a subsequent drought event. Journal of Ecology, 104(5), 1453-1465. https://doi.org/10.1111/1365-2745.12593

Galazka, A., Gawryjolek, K., Gajda, A., Furtak, K., Ksiezniak, A., \& Jończyk, K. (2018). Assessment of the glomalins content in the soil under winter wheat in different crop production systems. Plant Soil Environment, 64(1), 32-37. https://doi.org/10.17221/726/2017-PSE

Galindo, F. S., Ludkiewicz, M. G. Z., Bellote, J. L. M., Santini, J. M. K., Teixeira Filho, M. C. M., \& Buzetti, S. (2015). Épocas de inoculação com Azospirillum brasilense via foliar afetando a produtividade da cultura do trigo irrigado. Tecnologia e Ciência Agropecuária, 9(2), 43-48.

Geng, S. M., Yan, D. H., Zhang, T. X., Weng, B. S., Zhang, Z. B., Qin, T. L. (2015). Effects of drought stress on agriculture soil. Natural Hazards, 75, 1997-2011. https://doi.org/10.1007/s11069-014-1409-8

Gerdemann, J. W., \& Nicolson, T. H. (1963). Spores of mycorrhizal Endogone species extracted from soil by wet sieving and decanting. Transactions of the British Mycological Society, 46(2), 235-244. https://doi.org/ 10.1016/S0007-1536(63)80079-0

Giovannetti, M., \& Mosse, B. (1980). An evaluation of techniques to measuring vesicular arbuscular mycorrhizal infections in roots. New Phytologist, 84(3), 489-500. https://doi.org/10.1111/j.1469-8137.1980.tb04556.x

Gomide, P. H. O., Santos, J. G. D., Siqueira, J. O., \& Soares, C. R. F. S. (2009). Diversidade e Função de fungos micorrízicos arbusculares em sucessão de espécies hospedeiras. Pesquisa Agropecuária Brasileira, 44(11), 1483-1490. https://doi.org/10.1590/S0100-204X2009001100016

Hanks, R. J., Keller, J., Rasmussen, V. P., \& Wilson, G. D. (1976). Line Source Sprinkler for Continuous Variable Irrigation-crop Production Studies. Soil Science Society of America Journal, 40(3), 426-429. https://doi.org/10.2136/SSSAJ1976.03615995004000030033X

Hasibeder, R., Fuchslueger, L., Richter, A., \& Bahn, M. (2015). Summer drought alters carbon allocation to roots and root respiration in mountain grassland. New Phytologist, 205(3), 1117-1127. https://doi.org/10.1111/ nph.13146

Hossain, M. B. (2021). Glomalin and Contribution of Glomalin to Carbon Sequestration in Soil: A Review. Turkish Journal of Agriculture-Food Science and Technology, 9(1), 191-196. https://doi.org/10.24925/ turjaf.v9i1.191-196.3803

INMET (Instituto Nacional de Meteorologia). (2019). Clima-Gráficos Climatológicos (1931-1960 e 1961-1990). Retrieved from http://www.inmet.gov.br/portal/index.php?r=clima/graficosclimaticos

INVAM. (2021). International Culture Collection of Arbuscular and Vesicular-Arbuscular Mycorrhizal Fungi. Retrieved from http://invam.wvu.edu

Janusz, B. (2019). Arbuscular mycorrhizal fungi (Glomeromycota), Endogone and Complexipes species 
deposited in the Departament of Plant Pathology, University of Agriculture in Szczecin, Poland. Retrieved from http://www.zor.zut.edu.pl/Glomeromycota/Species descriptions of AMF.html

Jia, X., Zhao, Y., Liu, T., Huang, S., \& Chang, Y. (2016). Elevated $\mathrm{CO}_{2}$ increases glomalin-related soil protein (GRSP) in the rhizosphere of Robinia pseudoacacia $\mathrm{L}$. seedlings in $\mathrm{Pb}$ - and Cd-contaminated soils. Environmental Pollution, 218, 349-357. https://doi.org/10.1016/j.envpol.2016.07.010

Labuschagne, J., van Zyl, J., Agenbag, G. A., Crous, I. R., \& Hoffman, J. E. (2020). Effect of once-off tillage on soil water, inorganic nitrogen and glomalin contents under conservation agriculture in the Swartland sub-region of the Western Cape. South African Journal of Plant and Soil, 37(4), 273-282. https://doi.org/ $10.1080 / 02571862.2020 .1750069$

Lehnert, H., Serfling, A., Enders, M., Friedt, W., \& Ordon, F. (2017). Genetics of mycorrhizal symbiosis in winter wheat (Triticum aestivum). New Phytologist, 215(2), 779-791. https://doi.org/10.1111/nph.14595

Léon, D. G. de, Vahter, T., Zobel, M., Koppel, M., Edesi, L., Davison, J., ... Opik, M. (2020). Different wheat cultivars exhibit variable responses to inoculation with arbuscular mycorrhizal fungi from organic and conventional farms. PLoS ONE, 15(5), 1-17. https://doi.org/10.1371/journal.pone.0233878

Lombardo, L., Palese, A. M., Grasso, F., Duffy, D. H., Bati, C. B., \& Xiloyannis, C. (2019). Mechanical tillage diversely affects glomalin content, water stable aggregates and AM fungal community in the soil profiles of two differently managed olive orchards. Biomolecules, 9(10). https://doi.org/10.3390/biom9100639

Mendes, I. C., Souza, L. M., Sousa, D. M. G., Lopes, A. A. C., Reis-Junior, F. B., Lacerda, M. P. C., \& Malaquias, J. V. (2019). Critical limits for microbial indicators in tropical Oxisols at post-harvest: The FERTBIO soil sample concept. Applied Soil Ecology, 139(March), 85-93. https://doi.org/10.1016/ j.apsoil.2019.02.025

Nahar, K., Bovill, B., \& McDonald, G. (2020). Mycorrhizal colonization in bread wheat varieties differing in their response to phosphorus. Journal of Plant Nutrition, 44(1), 29-45. https://doi.org/10.1080/01904167. 2020.1793190

Nunes, H. B., Goto, B. T., Coimbra, J. L., Oliveira, J. S., Tavares, D. G., Rocha, M. S., .. Soares, A. C. F. (2019). Is arbuscular mycorrhizal fungal species community affected by cotton growth management systems in the Brazilian cerrado? Anais Da Academia Brasileira de Ciencias, 91(4), 20180695. https://doi.org/10.1590/ 0001-3765201920180695

Nyamwange, M. M., Njeru, E. M., Mucheru-Muna, M., \& Ngetich, F. (2018). Soil management practices affect arbuscular mycorrhizal fungi propagules, root colonization and growth of rainfed maize. AIMS Agriculture and Food, 3(2), 120-134. https://doi.org/10.3934/agrfood.2018.2.120

Phillps, J. M., \& Hayman, D. S. (1970). Improved procedures for cleaning roots and staining parasitic and vesicular arbuscular mycorrhizal fungi for rapid assesement of infection. Transactions of the British Mycological Society London, 55, 458-161. https://doi.org/10.1016/S0007-1536(70)80110-3

Pontes, J. S. de, Oehl, F., Pereira, C. D., de Toledo Machado, C. T., Coyne, D., da Silva, D. K. A., \& Maia, L. C. (2017). Diversity of arbuscular mycorrhizal fungi in the Brazilian's Cerrado and in soybean under conservation and conventional tillage. Applied Soil Ecology, 117, 178-189. https://doi.org/10.1016/j.apsoil. 2017.04.023

Rani, B., Madan, S., Pooja, Sharma, K. D., Kumari, N., \& Kumar, A. (2018). Mitigating the effect of drought stress on yield in wheat (Triticum aestivum) using arbuscular mycorrhiza fungi (Glomus mosseae). Indian Journal of Agricultural Sciences, 88(12), 1903-1908.

Schalamuk, S., \& Cabello, M. (2010). Arbuscular mycorrhizal fungal propagules from tillage and no-tillage systems: Possible effects on Glomeromycota diversity. Mycologia, 102(2), 261-268. https://doi.org/10.3852/ 08-118

Shewry, P. R., \& Hey, S. J. (2015). The contribution of wheat to human diet and health. Food and Energy Security, 4(3), 178-202. https://doi.org/10.1002/FES3.64

Silva, A. M. M., Ramos, M. L. G., Nascimento, R. S. D. M. P., Silva, A. D. N., Silva, S. B., Cardoso, E. J. B. N., \& Paula, A. M. (2019). Soil quality indicators under management systems in a Quilombola community in the Brazilian Cerrado. Scientia Agricola, 76(6), 518-526. https://doi.org/10.1590/1678-992x-2018-0008

Silva, A. N., Ramos, M. L. G., Ribeiro Junior, W. Q., Alencar, E. R., Silva, P. C., Lima, C. A., ... Silva, M. A. V. (2020). Water stress alters physical and chemical quality in grains of common bean, triticale and wheat. 
Agricultural Water Management, 231, 106023. https://doi.org/10.1016/j.agwat.2020.106023

Silva, M., Soares Sobrinho, J., Albrecht, J. C., Chagas, H. J., Caierão, E., Moresco, É. R., ... Scheeren, P. L. (2015). BRS 404-Nova cultivar de trigo de sequeiro para o Cerrado brasileiro. Reunião da Comissão Brasileira de Pesquisa de Trigo e Triticale, 8; Seminário Técnico do Trigo, 9, 2014, Canela; Reunião da Comissão Brasileira de Pesquisa de Trigo e Triticale, 9; Seminário Técnico do Trigo, 10. Passo Fundo: Biotrigo Genética: Embrapa Trigo.

Soares, G. F., Ribeiro Júnior, W. Q., Pereira, L. F., Lima, C. A., Soares, D. S., Muller, O., ... Ramos, M. L. G. (2021). Characterization of wheat genotypes for drought tolerance and water use efficiency. Scientia Agricola, 78(5), e20190304. http://doi.org/10.1590/1678-992X-2019-0304

Soil Survey Staff. (2010). Keys to Soil Taxonomy (11th ed.). Washington, DC, USA: USDA-Natural Resources Conservation Service.

Steinberg, P. D., \& Rillig, M. C. (2003). Differential decomposition of arbuscular mycorrhizal fungal hyphae and glomalin. Soil Biology and Biochemistry, 35(1), 191-194. https://doi.org/10.1016/S0038-0717(02)00249-3

Vance, E. D., Brookes, P. C., \& Jenkinson, D. S. (1987). An extraction method for measuring soil microbial biomass C. Soil Biology and Biochemistry, 19(6), 703-707. https://doi.org/10.1016/0038-0717(87)90052-6

Vlček, V., \& Pohanka, M. (2020). Glomalin - an interesting protein part of the soil organic matter. Soil and Water Research, 15(2), 67-74. https://doi.org/10.17221/29/2019-SWR

Walkley, A., \& Black, I. A. (1934). An examination of the Degtjareff method for determining soil organic matter and a proposed modification of the chromic acid titration method. Soil Science, 37, 29-38. https://doi.org/ 10.1097/00010694-193401000-00003

Wang, W., Zhong, Z., Wang, Q., Wang, H., Fu, Y., \& He, X. (2017). Glomalin contributed more to carbon, nutrients in deeper soils, and differently associated with climates and soil properties in vertical profiles. Scientific Reports, 7(1), 1-13. https://doi.org/10.1038/s41598-017-12731-7

Wilkes, T. I., Warner, D. J., Edmonds-Brown, V., Davies, K. G., \& Denholm, I. (2021). Zero tillage systems conserve arbuscular mycorrhizal fungi, enhancing soil glomalin and water stable aggregates with implications for soil stability. Soil Systems, 5(1), 1-13. https://doi.org/10.3390/soilsystems5010004

Wright, S. F., \& Upadhyaya, A. (1996). Extraction of an abundant and unusual protein from soil and comparison with hyphal protein of arbuscular mycorrhizal fungi. Soil Science, 61(9), 575-586. https://doi.org/ 10.1097/00010694-199609000-00003

Zhao, W., Liu, L., Shen, Q., Yang, J., \& Han, X. (2020). Effects of Water Stress on Photosynthesis, Yield, and Water Use Efficiency in Winter Wheat. Water, 12(8), 2127. https://doi.org/10.1037/1061-4087.45.2.10

\section{Notes}

Note 1. A meteorological phenomenon common in the southern and middle-east regions of Brazil, consisting of a period of drought, accompanied by intense heat $\left(25-35{ }^{\circ} \mathrm{C}\right.$; 77-95 $\left.{ }^{\circ} \mathrm{F}\right)$, intense sunshine, and low relative humidity in the middle of the rainy season or in the middle of winter.

\section{Copyrights}

Copyright for this article is retained by the author(s), with first publication rights granted to the journal.

This is an open-access article distributed under the terms and conditions of the Creative Commons Attribution license (http://creativecommons.org/licenses/by/4.0/). 